\title{
Formation and Isolation of Leucocidin from Pseudomonas aeruginosa
}

\author{
By W. SCHARMANN* \\ Institut für Bakteriologie und Immunologie, Fachbereich Veterinärmedizin, \\ Universität Giessen, D-63 Giessen, Germany
}

(Received 6 June 1975; revised 19 September 1975)

\begin{abstract}
SUMMARY
A toxic substance, which destroyed leucocytes from man but was inactive against erythrocytes, was demonstrated in cultures of four out of I IO strains of Pseudomonas aeruginosa tested. The toxin, designated 'leucocidin', was cell-bound as a precursor toxin, exhibiting little or no toxicity. It was converted into toxin with maximum activity by various proteases including an endogenous elastase. The production of leucocidin was directly proportional to the number of bacteria and was not influenced by variations in media, iron concentration, $\mathrm{pH}$ or temperature. The best method for large-scale production of leucocidin was autolysis of washed bacteria.
\end{abstract}

\section{INTRODUCTION}

Sepsis due to Pseudomonas aeruginosa is often characterized by the absence of leucocytosis (Helm \& Stille, I972) or even by leucopenia (Schaffer \& Oppenheimer, I948; Foley et al., 1969). Accordingly, local tissue neutropenia is a frequent symptom in necrotic lesions caused by $P$. aeruginosa (Fraenkel, I912; Moncrief \& Teplitz, I964; Foley et al., 1969). Neutrophils, if present, are found at the margin of the necrotic area and show pycnotic nuclei and disruption of the cytoplasm (Hubbard, King \& Beamer, I957; Teplitz, 1965). The reason for the absence of a polymorphonuclear leucocyte response had not yet been elucidated but may be due to toxic products of the bacterium (Teplitz, I965). This is supported by the rapid distintegration of neutrophils after exposure to $P$. aeruginosa in vitro (Hubbard et al., I957).

Sensakovic \& Bartell (1974) reported that the extracellular slime of $P$. aeruginosa caused leucopenia in mice and Liu (I974) detected a rapid reduction of circulating leucocytes after injection of exotoxin A into mice.

This paper reports the isolation from $P$. aeruginosa of another toxic substance which exerts a specific cytotoxic action on human leucocytes.

\section{METHODS}

Bacteria. One hundred and ten strains of $P$. aeruginosa were isolated from human and animal patients and from milk samples of cows. The strains were identified as $P$. aeruginosa according to Hugh (1970) and were pyocin typed by the 'fingerprinting' method of Farmer \& Herman (1969). Strain 158 , which was used for the production of leucocidin, had been isolated from milk. It was positive for the pyocin indicator strains 2, 3, 5, 6, 8, I3, 14, (16), 9, 22, 26 and for pyocins $A$ to $G, I, K, M$ to $Q$, and T.

Culture media. The following media were used: nutrient broth, brain-heart infusion

* Present address: Bundesgesundheitsamt, D-I Berlin 33, Postfach, Germany. 
broth, tryptic soy broth (TSB) and tryptic soy agar (TSA), all from Difco; the complex medium (MO) of Morihara et al. (I965); and a minimal medium (Pulverer \& Korth, I96I) containing $2 \%(\mathrm{w} / \mathrm{v})$ glucose as carbon source.

Cultivation techniques. Pseudomonas aeruginosa was inoculated from fresh TSA slants into I00 $\mathrm{ml}$ Erlenmeyer flasks containing $20 \mathrm{ml}$ medium. The flasks were shaken at $140 \mathrm{rev} . / \mathrm{min}$ at $3 \mathrm{I}^{\circ} \mathrm{C}$ for $\mathrm{I} 2 \mathrm{~h}$. Erlenmeyer flasks ( $\mathrm{I}$ l) containing $50 \mathrm{ml}$ medium were inoculated with $0.5 \mathrm{ml}$ of this culture and incubated for $22 \mathrm{~h}$ at $3 \mathrm{I}{ }^{\circ} \mathrm{C}$ on a rotating shaker at $\mathrm{I} 4 \mathrm{O} \mathrm{rev} . / \mathrm{min}$. The bacteria were then separated from the culture fluid by centrifugation $(27300 \mathrm{~g}, 20 \mathrm{~min})$ and washed once with phosphate buffered saline (PBS) pH $7 \cdot 2$ (Dulbecco \& Vogt, 1954).

Formation of enzymes. The production of protease was determined on TSA containing I $\%(w / v)$ sodium caseinate (Difco). Elastase was assayed on elastin agar plates (Sbarra, Gilfillan \& Bardawil, 1960). Lipase production was detected on tributyrin agar (Oxoid). Lecithinase activity was determined on TSA containing $5 \%(\mathrm{v} / \mathrm{v})$ egg yolk (Oxoid).

Determination of growth. Viable count determinations were made by the pour plate method in which dilutions of the culture were added to molten TSA at $50{ }^{\circ} \mathrm{C}$.

Assay of toxins and enzymes. Leucocidic activity was assayed by the microscopic slide adhesion method (Gladstone \& van Heyningen, I957) with human granulocytes. The slides had a number of fields $(0.6 \mathrm{~mm}$ in diameter each) which were prepared by fixing a piece of punched parafilm on the glass. Serial dilutions of the toxin in PBS were incubated with the cells at $37^{\circ} \mathrm{C}$ for $60 \mathrm{~min}$ in a moist chamber. One MLeD (minimal leucocidic dose) was the highest dilution of toxin which destroyed all the leucocytes of a field (about 6000 to 8000 granulocytes). The haemolytic activity was determined as described by Bernheimer \& Schwartz (1963) with sheep erythrocytes. Protease activity was assayed as described previously (Scharmann \& Balke, 1974) with casein (Hammarsten) as substrate. Leucine arylamidase (LAA) activity was measured by the method of Martinek, Berger \& Broida (I964), the unit of activity being defined as the amount of enzyme which liberated I $\mu \mathrm{mol}$ $\beta$-naphthylamine from L-leucyl- $\beta$-naphthylamide per hour at $37^{\circ} \mathrm{C}$ and $\mathrm{pH} 7 \cdot \mathrm{I}$. The enzyme was not a leucine aminopeptidase, as L-leucine amide was not split. Protein was determined by the method of Lowry et al. (195I) with bovine serum albumin as the standard.

Distintegration of bacteria. Washed bacteria resuspended in PBS at $10^{11}$ cells $/ \mathrm{ml}$ were used. Ultrasonic disruption was done at $20 \mathrm{kHz}$ in a $125 \mathrm{~W}$ Branson sonifier S I25 (Branson Instruments Inc., Danbury, Connecticut, U.S.A.). Treatment periods of $15 \mathrm{~s}$ were alternated with intervals of $\mathrm{I}$ to $2 \mathrm{~min}$ to avoid heat denaturation of the toxin. In addition, the treated tube was immersed in a $-10{ }^{\circ} \mathrm{C}$ bath during sonication. After 10 to 15 sonications the sample was centrifuged ( 3 I $000 \mathrm{~g}, 20 \mathrm{~min}$ ), and the supernatant collected.

As an alternative to sonication, bacteria were lysed for up to $72 \mathrm{~h}$ at $4{ }^{\circ} \mathrm{C}$ with $0.6 \%$ $(\mathrm{w} / \mathrm{v})$ sodium deoxycholate. In lysis experiments with mitomycin $\mathrm{C}\left(0.5 \mu \mathrm{g} \mathrm{ml}^{-1}\right)$ or carbenicillin $\left(500 \mu \mathrm{g} \mathrm{ml}^{-1}\right)$ the antibiotics were added to the culture in the exponential phase of growth ( $\mathrm{I} 2 \mathrm{~h}$ after inoculation, $8 \times \mathrm{IO}^{9} \mathrm{cells} / \mathrm{ml}$ ), incubation was continued for $4 \mathrm{~h}$ at $37^{\circ} \mathrm{C}$ and the supernatant collected by centrifugation (3 $1000 \mathrm{~g}, 20 \mathrm{~min})$.

Chemicals. Trypsin, chymotrypsin, elastase from pig pancreas, pronase, DNAase from bovine pancreas, egg-white lysozyme, cysteine, 2-mercaptoethanol, $N$-I-naphthylethylenediamine, L-leucine amide and polyethylene glycol 20000 , were obtained from Serva, Heidelberg, Germany. L-Leucyl- $\beta$-naphthylamide was obtained from Sigma. Ammonium sulphamate was purchased from Fluka, Buchs, Switzerland. Carbenicillin was a generous gift from Beecham Pharma, Mainz, Germany. All other chemicals were obtained from Merck. 


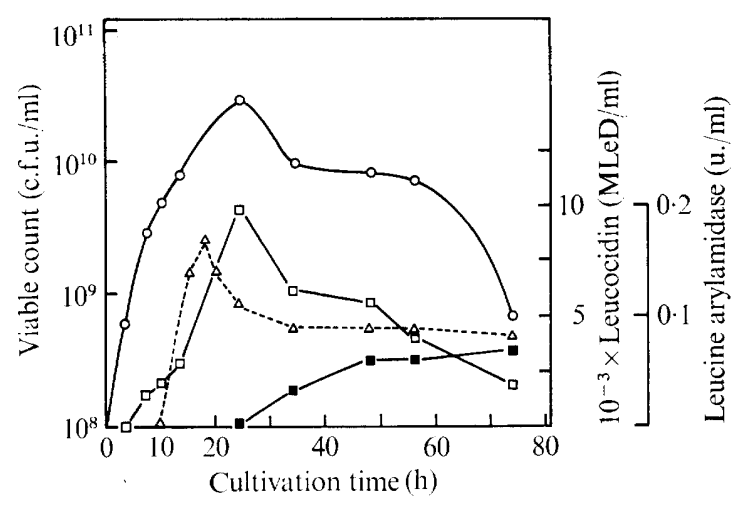

Fig. I. Production of leucocidin as a function of time. Pseudomonas aeruginosa strain 158 was shaken at $3 \mathrm{I}^{\circ} \mathrm{C}$ in tryptic soy broth supplemented with $5 \%(\mathrm{w} / \mathrm{v})$ glucose. $\bigcirc$, Viable count; $\square$, leucocidic activity in the supernatant of autolysed bacteria (washed, Io-fold concentrated); $\mathbf{\square}$, leucocidic activity in culture supernatant; $\triangle$, leucine arylamidase activity in culture supernatant.

\section{RESULTS}

\section{Evidence for leucocidin}

Preliminary experiments with $P$. aeruginosa had shown that individual strains of this species contained a leucocidic substance that was not identical with haemolysin. The cytotoxic effects of haemolysin were characterized by lysis of both erythrocytes and leucocytes from man. On the other hand 'leucocidin', as the other toxin was designated, damaged human leucocytes of all types in a specific manner but was inactive against erythrocytes. The cytopathic effect of leucocidin was marked by rapid and massive swelling of the leucocytes without rupture of the cell membrane (Scharmann, Jacob \& Porstendörfer, I976).

In TSB medium with $5 \%(\mathrm{w} / \mathrm{v})$ glucose, I IO strains of $P$. aeruginosa were examined for leucocidic activity and the toxin was found in the cell-free supernatants of four strains after 60 to $70 \mathrm{~h}$ growth at $37^{\circ} \mathrm{C}$. Strain 158 showed the highest leucocidic activity. The ability to produce leucocidin was lost during cultivation of the Pseudomonads on synthetic media. No correlation was found between leucocidin and various enzymes produced by the Pseudomonads such as proteinase (elastase), lecithinase $\mathrm{C}$ and lipase, since not only the leucocidinpositive, but also most of the leucocidin-negative strains produced these enzymes.

Haemolysin, which was also released into the culture supernatant in low amounts and interferred with the leucocidin test, could be eliminated from the supernatant by selective adsorption to aluminium oxide coated with cholesterol (Kanoe, Blobel \& Schaeg, 1969).

\section{Production of leucocidin}

When $P$. aeruginosa, strain $\mathrm{I} 58$, was cultivated in TSB and shaken at $3 \mathrm{I}^{\circ} \mathrm{C}$, leucocidin appeared in the cell-free supernatant only during the autolytic phase of growth between 24 and $80 \mathrm{~h}$ (Fig. I). In contrast, leucine arylamidase activity which was used as an intracellular marker (Matheson, I963) was detected as early as Io to I $2 \mathrm{~h}$ after inoculation of the medium and reached a peak at about $17 \mathrm{~h}$. Leucocidin was also obtained from washed, autolysed cells: the bacteria were harvested at different phases of growth, washed once with PBS and resuspended in PBS, either in the original volume of the culture or in one-tenth of it. The suspension of washed cells was shaken for $73 \mathrm{~h}$ at $37^{\circ} \mathrm{C}$ and the supernatant of the 


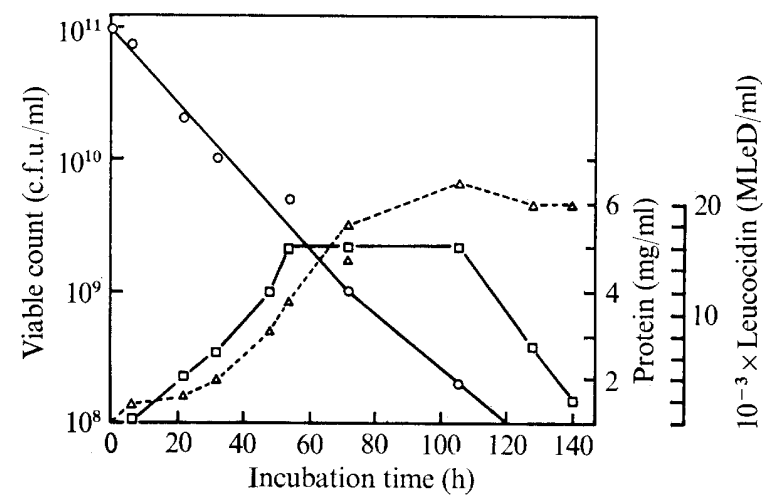

Fig. 2. Liberation of leucocidin by autolysis of $P$. aeruginosa. A I 1 Erlenmeyer flask, containing $10^{13}$ bacteria in $100 \mathrm{ml}$ PBS was shaken at $37^{\circ} \mathrm{C}$. $O$, Viable count; $\square$, leucocidic activity and $\triangle$, protein content of supernatant of autolysed bacteria.

autolysate collected by centrifugation $(37000 \mathrm{~g}, 40 \mathrm{~min})$. Leucocidic activity thus liberated by autolysis was found to be correlated with the number of viable cells of the growth cycle (Fig. I).

To determine the optimal conditions for leucocidin production, $P$. aeruginosa strain I58 was grown in various media (Table $\mathrm{I}$ ) at $3 \mathrm{I}{ }^{\circ} \mathrm{C}$ and the bacteria harvested at $20 \mathrm{~h}$, washed and autolysed. MO medium gave the highest yield. With all media the formation of leucocidin was directly proportional to the number of bacteria. Autolysates of cultures grown at $3 \mathrm{I}^{\circ} \mathrm{C}$ yielded the highest leucocidic activity, since $P$. aeruginosa I 58 grew better at this temperature than at 25 or $37^{\circ} \mathrm{C}$. Media adjusted to different $\mathrm{pH}$ values failed to reveal any direct influence of $\mathrm{pH}$ on toxin formation, and the highest leucocidic activity was measured between $\mathrm{pH} 7.0$ and 8.0 where the maximum growth was obtained. Addition of $\mathrm{Fe}^{2+}$ ( $0 . \mathrm{I}$ to $100 \mu \mathrm{g} \mathrm{ml}^{-1}$ ), an important factor for the production of various toxins (Dubos \& Geiger, I946; Pappenheimer \& Johnson, I936), had no effect on the formation of leucocidin. Cultivation of $P$. aeruginosa on cellophane-over-agar (TSA), the method for the production of haemolysin and lecithinase C from $P$. aeruginosa chosen by Liu (1964), yielded only about half the amount of leucocidin that was obtained from broth cultures with the equivalent number of bacteria.

\section{Solubilization of leucocidin from $P$. aeruginosa by autolysis and ultrasonication}

Various methods for liberating leucocidin from the bacteria were tried but the best was autolysis by shaking the washed cells in PBS for 56 to $106 \mathrm{~h}$ at $37^{\circ} \mathrm{C}$ (Fig. 2). Sodium thioglycolate (0. I to $0.7 \%$; Seki et al., I954), toluene (0.5\%; Brown et al., 1970$)$ or $\mathrm{KCl}(0.5$ to $\mathrm{I} \cdot \mathrm{O} \mathrm{M})$ had no effect on leucocidic activity in the autolysis supernatants. Only a part of the total activity that was bound to the organisms could be obtained by autolysis. The supernatant of a TSB culture contained a leucocidic activity three times higher than the supernatant of an autolysate with a comparable number of cells. Probably the loss of toxin was due to surface denaturation during shaking the autolysate at $37^{\circ} \mathrm{C}$. No inhibitor for leucocidin could be detected in the autolysate nor was the toxin destroyed by the purified protease (elastase) (Scharmann \& Balke, 1974) of the same strain. When the washed bacteria were disrupted by ultrasonication, leucocidic activity in the homogenate or in its supernatant obtained by centrifugation was very low. However, the toxicity increased when the sonicated cultures were kept at $37^{\circ} \mathrm{C}$ for $6 \mathrm{~h}$ and it increased up to 90-fold when the homogenate was 


\section{Table I. Production of leucocidin by $P$. aeruginosa strain 158 in various media}

The conditions for cultivation are described in Methods. Cultures were shaken for $20 \mathrm{~h}$ at $3 \mathrm{I}^{\circ} \mathrm{C}$. Leucocidic activity was measured in the supernatant of autolysed washed bacteria.

\begin{tabular}{|c|c|c|c|c|}
\hline Medium & $\begin{array}{c}10^{-8} \times \text { Viable count } \\
\text { (c.f.u. } / \mathrm{ml})\end{array}$ & $\begin{array}{c}\mathrm{IO}^{-2} \times \text { Leucocidin } \\
(\mathrm{MLeD} / \mathrm{ml})\end{array}$ & $\begin{array}{l}\text { Protein } \\
(\mathrm{mg} / \mathrm{ml})\end{array}$ & $\begin{array}{c}\text { Specific activity } \\
\text { (MLeD leucocidin/mg } \\
\text { protein) }\end{array}$ \\
\hline MM & 9 & 8 & 0.87 & 920 \\
\hline NB & 50 & 40 & $\mathrm{I} \cdot 23$ & 3252 \\
\hline BHI & 100 & 60 & $5 \cdot 8 I$ & 1032 \\
\hline TSB & 100 & 80 & $5 \cdot 43$ & 1473 \\
\hline TSB, I \% (w/v) glucose & 80 & 55 & $5 \cdot 10$ & 1078 \\
\hline $\mathrm{TSB}, 2 \%(\mathrm{w} / \mathrm{v})$ glucose & 70 & 50 & $5 \cdot 70$ & 877 \\
\hline TSB, $5 \%(w / v)$ glucose & 130 & 90 & $5 \cdot 20$ & 1730 \\
\hline $\mathrm{MO}$ & 160 & 100 & $8 \cdot 45$ & I 183 \\
\hline
\end{tabular}

MM, minimal medium; NB, nutrient broth; BHI, brain heart infusion broth; TSB, tryptic soy broth; MO, Morihara's medium; c.f.u., colony-forming units; MLeD, minimal leucocidic dose.

incubated with trypsin (100 $\mu \mathrm{g} \mathrm{ml}^{-1}$ ) or purified protease from $P$. aeruginosa strain 158 , for $\mathrm{I} h$. Control experiments showed that the enhancement of leucocidic activity was not due to synergistic action of protease and leucocidin. EDTA (O.I to $0.02 \mathrm{M}), 2$-mercaptoethanol $(0.6 \mathrm{M})$ or cysteine (IO mM) did not affect the toxic activity of the sonicated suspension. These results suggested that leucocidin was bound to subcellular structures of the bacteria as a 'precursor' toxin with no, or only low, specific toxicity. The conversion of the precursor into the toxin required partial degradation by the protease and probably also by other autolytic enzymes of the Pseudomonads.

Gel filtration confirmed the above speculations. When ultrasonicated homogenate was applied to a Sephadex G-I50 superfine column, leucocidin with low toxicity eluted shortly after the void volume, trailing about half the length of the elution diagram; this was detected after incubation of the fractions with trypsin (Fig. $3 a$ ). The tubes containing leucocidin were then pooled, concentrated by dialysis against polyethylene glycol 20000 and fractionated again under identical conditions. Leucocidin then appeared in the middle of the elution diagram as a sharp peak (Fig $3 b$ ). When the supernatant of autolysed bacteria was applied to the same column the toxin eluted at a similar position (Fig. $3 c$ ).

The release of active toxin from sonicated suspensions by several proteases of different peptide bond specificities was measured. Trypsin, chymotrypsin, pancreatic elastase, papain, subtilisin $\mathrm{BNP}^{1}$, subtilisin Carlsberg and purified $P$. aeruginosa elastase all liberated the same amount of leucocidic activity, but pronase destroyed the toxin.

\section{Release of leucocidin from $P$. aeruginosa by other methods}

As autolysis of the bacteria was accompanied by a substantial loss of leucocidin and ultrasonication proved to be unsuitable for toxin production on a large scale, other methods for detaching leucocidin from the bacteria were tried.

To avoid denaturation of the toxin at $37^{\circ} \mathrm{C}$, lysis of washed bacteria was induced by sodium deoxycholate $\left(0.6 \%\right.$ ) at $4{ }^{\circ} \mathrm{C}$, but only low leucocidic activity was obtained. This may have been due to a reduced action of the protease at $4{ }^{\circ} \mathrm{C}$, since leucocidic activity increased upon incubation at $37^{\circ} \mathrm{C}$ and after treatment with trypsin. However, this method did not yield higher amounts of leucocidin than autolysis (Table 2). Sodium deoxycholate $(\mathrm{r} \cdot 6 \%, \mathrm{w} / \mathrm{v})$ at $37^{\circ} \mathrm{C}$ caused lysis but also a dramatic increase in viscosity due to the release of DNA. Only small amounts of precursor toxin could be separated from this jelly-like 


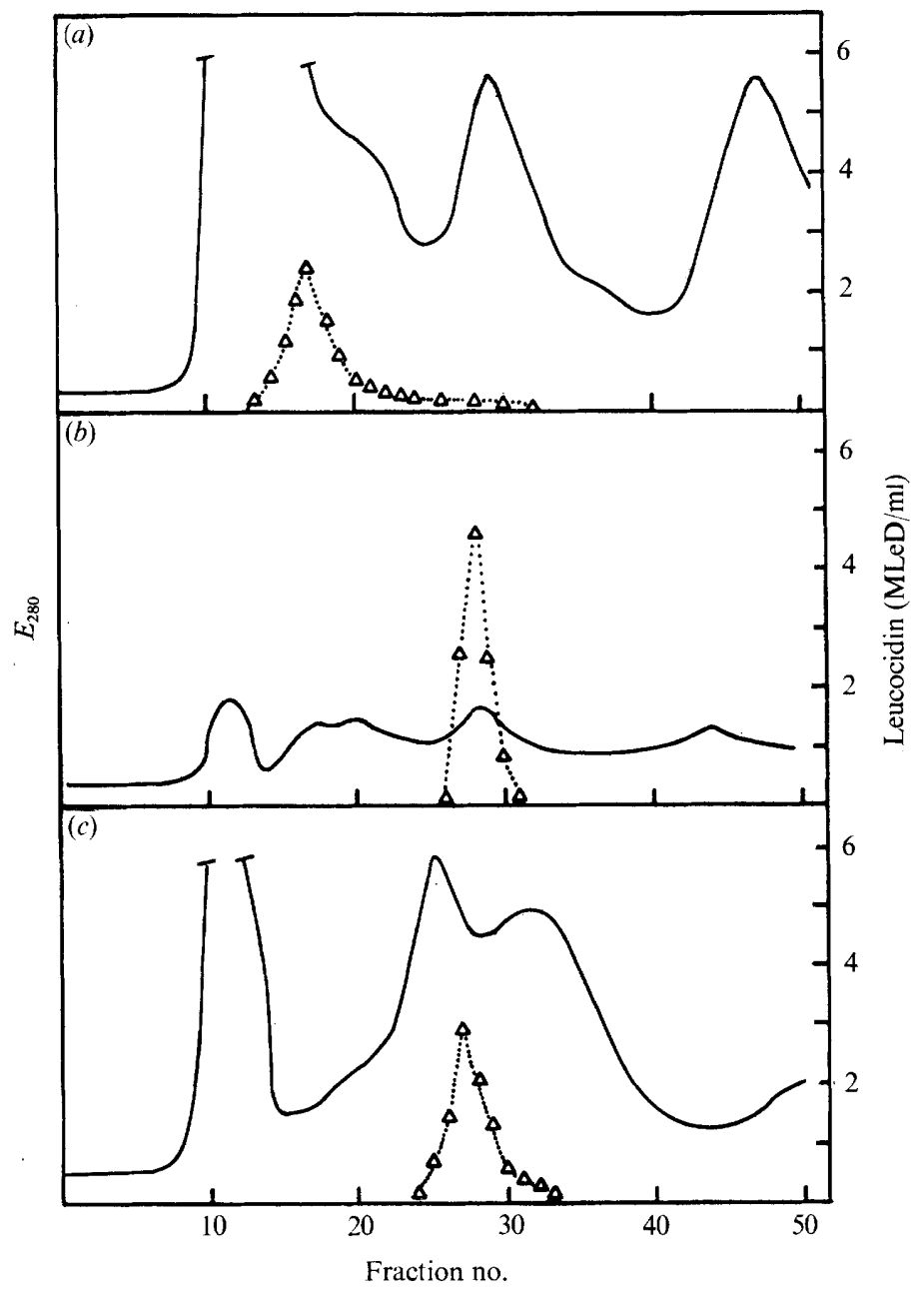

Fig. 3. Gel filtration of different leucocidin preparations on Sephadex G-150 superfine. The column $(2.5 \times 45 \mathrm{~cm})$ was equilibrated and eluted with PBS containing $0.2 \mathrm{M}-\mathrm{NaCl}$. Fractions $(4 \mathrm{ml})$ were collected. The following samples were applied: (a) Supernatant fluid of sonicated homogenate ( $24 \mathrm{mg}$ protein); leucocidic activity in the fractions was assayed after trypsination. (b) Pooled and concentrated leucocidin-containing fractions from experiment $a$. (c) Supernatant fluid of autolysed bacteria. $\longrightarrow$, Protein $\left(E_{280}\right) ; \triangle \ldots \triangle$, leucocidic activity.

mass. The lysate was therefore liquefied by the addition of DNAase $\left(100 \mu \mathrm{g} \mathrm{ml}^{-1}\right)$ and the supernatant collected by centrifugation. After dialysis and incubation with trypsin, its leucocidic activity was only slightly higher than that of the autolysate obtained from a similar number of bacteria (Table 2). Lysis of the bacteria with mitomycin $\mathrm{C}$ or carbenicillin yielded the highest leucocidic activity (Table 2). By these methods, I MLeD leucocidin was obtained from $3 \times 10^{6}$ bacteria. However, these antibiotics were too expensive for toxin production on a large scale.

Addition of EDTA (r $\mu \mathrm{mol} \mathrm{m}{ }^{-1}$ ) to $P$. aeruginosa, which had been washed in PBS and resuspended in $0.03 \mathrm{M}$-tris solution, gave maximal lysis after $3 \mathrm{~h}$ incubation at $37^{\circ} \mathrm{C}$ but only a very small amount of active toxin was liberated, since the protease is inhibited by EDTA (Balke \& Scharmann, I974). After the addition of trypsin or $\mathrm{CaCl}_{2}$ (O.I M), toxicity 
Table 2. Release of leucocidin by various treatments

For all experiments (except lysis by antibiotics) $10^{11}$ washed bacteria $/ \mathrm{ml}$ were used. For lysis by antibiotics the results were extrapolated to $10^{11}$ cells $/ \mathrm{ml}$. The supernatant fluids of the cell homogenates (except autolysate) were incubated with trypsin $(100 \mu \mathrm{g} / \mathrm{ml})$ for $\mathrm{I} \mathrm{h}$ at $37^{\circ} \mathrm{C}$ and dialysed exhaustively against PBS.

Method of disintegration
Autolysis
Ultrasonication
Deoxycholate $\left(0 \cdot 6 \%, 4{ }^{\circ} \mathrm{C}\right)$
Deoxycholate $\left(1.6 \%, 37^{\circ} \mathrm{C}\right)$
Mitomycin
Carbenicillin
Tris-EDTA

Method of disintegration
$10^{-2} \times$ Leucocidic activity $(\mathrm{MLeD} / \mathrm{ml})$ in the supernatant fluids

was enhanced (up to $70-$-fold) in the supernatant of the lysate to a level which was about $50 \%$ higher than that of autolysate. Although maximal lysis of $P$. aeruginosa strain I 58 with tris ( $\mathrm{pH}$ 9)-EDTA alone took about $3 \mathrm{~h}$, added lysozyme $\left(50 \mu \mathrm{g} \mathrm{ml}^{-1}\right)$ caused immediate lysis (Heilmann, 1972). High-speed centrifugation $(40000 \mathrm{~g}, 60 \mathrm{~min})$ of the jelly-like mass yielded only a small quantity of supernatant. It contained the precursor leucocidin in amounts which were only slightly higher than those obtained by autolysis of a comparable number of bacteria.

\section{DISCUSSION}

These experiments demonstrate the production of a hitherto unknown toxic substance by $P$. aeruginosa. The toxin damaged leucocytes without causing haemolysis and was therefore designated 'leucocidin' by analogy with the Panton-Valentine leucocidin of Staphylococcus aureus. Leucocidin of $P$. aeruginosa did not correspond with other known cytotoxic substances such as exotoxin (Pavlovskis \& Gordon, 1972), haemolysin (Scharmann, Köster \& Blobel, I973) or the protease (elastase)(Pflüger, Scharmann \& Blobel, I975). Only four of I Io tested $P$. aeruginosa strains revealed leucocidic activity. However, the occurrence of leucocidin-positive strains might be higher in vivo, since the ability to produce toxin is lost on synthetic media.

Leucocidin was cell-bound in the form of a precursor toxin with no, or only low, toxic activity. It was converted into toxin with high toxicity by the action of the endogenous protease (elastase) of $P$. aeruginosa and by six other proteases with known specificity for peptide bonds. Urea, EDTA, 2-mercaptoethanol or alkaline $\mathrm{pH}$ did not release toxic activity, suggesting that the toxin was covalently bound by a peptide chain.

The late appearance of leucocidic activity in the culture supernatant, compared with the early appearance of the intracellular leucine arylamidase, suggests a special mode of toxin liberation. The four leucocidin-positive strains also produced high protease (elastase) activity. The occurrence of precursor toxins or 'protoxins' converted into toxins by proteolytic enzymes had previously been described only for Clostridia, for example with Clostridium botulinum type A, B, E and F (Lamanna \& Sakaguchi, 197I) and with $\mathrm{Cl}$. perfringens type D (Turner \& Rodwell, I943).

The best method for making leucocidin on a large scale proved to be autolysis. However, about two-thirds of the toxin initially present in the bacteria was probably lost by surface denaturation.

This investigation was supported in part by the Deutsche Forschungsgemeinschaft. 


\section{REFERENCES}

Balke, E. \& Scharmann, W. (1974). Untersuchungen über eine Protease (Elastase) aus Pseudomonas aeruginosa. II. Characterisierung des Enzyms. Hoppe-Seyler's Zeitschrift für physiologische Chemie $\mathbf{3 5 5}$, 958-968.

Bernheimer, A. W. \& Schwartz, L. L. (1963). Isolation and composition of staphylococcal alpha toxin. Journal of General Microbiology 30, 56I-568.

Brown, J. A., West, W. L., Banks, W. M. \& Marshall, J. D. (I970). Some biological effects of a heat labile toxin from Pasteurella pseudotuberculosis. Cytobios 2, 199-205.

Dubos, R. J. \& GeIger, J. W. (I946). Preparation and properties of shiga toxin and toxoid. Journal of Experimental Medicine 84, I43-I 56.

Dulbecco, R. \& VoGT, M. ( I954). One-step growth curve of western equine encephalomyelitis virus chicken embryo cells grown in vitro and analysis of virus yield from single cells. Journal of Experimental Medicine 99, I83-199.

Farmer III, J. J. \& Herman, L. G. (1969). Epidemiological fingerprinting of Pseudomonas aeruginosa by the production of and sensitivity to pyocin and bacteriophage. Applied Microbiology 18, 760-765.

Foley, F. D., Greenawald, K. A., Nash, G. \& Pruitt, B. A. (1969). Pathology of Pseudomonas infection. Texas Medicine 63, 36-39.

Fraenkel, E. (1912). Über die Menschenpathogenität des Bacillus pyocyaneus. Zeitschrift für Hygiene und Infektionskrankheiten 72, 486-522.

Gladstone, G. P. \& van Heyningen, W. E. (1957). Staphylococcal leucocidins. British Journal of Experimental Pathology 38, 123-I 37.

Heilmann, H. D. (1972). On the peptidoglycan of the cell walls of Pseudomonas aeruginosa. European Journal of Biochemistry 3r, 456-463.

Helm, E. \& Stille, W. (1972). Klinik und Therapie der Sepsis durch Pseudomonas aeruginosa. Deutsche medizinische Wochenschrift 97, I584-1589.

Hubbard, J. D., King, H. \& Beamer, P. R. (I957). The pathogenicity of Pseudomonas aeruginosa. Experimental studies and report of a case. American Journal of Clinical Pathology 28, 243-257.

Hugh, R. (1970). Pseudomonas and Aeromonas. In Manual of Clinical Microbiology, pp. 175-190. Edited by J. E. Blair, E. H. Lenette and J. P. Truant. Bethesda, Maryland: American Society for Microbiology.

Kanoe, M., Blobel, H. \& Schaeg, W. (1969). Selektive Anreicherung von Staphylokokken-PantonValentine-Leukozidin mit Aluminium-Cholesterin. Zeitschrift für Naturforschung 24 b, I43 I-I 435.

Lamanna, C. \& SAKaguchi, G. (197I). Botulinal toxins and problem of nomenclature of simple toxins. Bacteriological Reviews 35, 242-249.

Liv, P. V. (I964). Factors that influence toxogenicity of Pseudomonas aeruginosa. Journal of Bacteriology 88, I42I-I427.

Liu, P. V. (1974). Extracellular toxins of Pseudomonas aeruginosa. Journal of Infectious Diseases 130, s94s99.

Lowry, O. H., Rosebrough, N. T., Farr, A. L. \& Randall, R. J. (I95I). Protein measurement with the Folin phenol reagent. Journal of Biological Chemistry 193, 265-275.

Martinek, R. G., Berger, L. \& Broida, D. (1964). Simplified estimation of leucine aminopeptidase activity. Clinical Chemistry ro, 1087-1097.

MAtheson, A. T. (1963). The localization and properties of an aminopeptidase in Escherichia coli B. Canadian Journal of Biochemistry 4I, 9-I8.

Moncrief, J. A. \& Teplitz, C. (1964). Changing concepts in burn sepsis. Journal of Trauma 4, 233245.

Morihara, K., Tsuzuki, H., OKa, T., Inoue, H. \& Ebata, M. (1965). Pseudomonas aeruginosa elastase: Isolation, crystallisation, and preliminary characterization. Journal of Biological Chemistry 240, 32953304 .

Pappenheimer, A. M. \& Johnson, S. J. (1936). Studies in diphtheria toxin production. I. The effect of copper and iron. British Journal of Experimental Medicine 17, 335-34I.

Pavlovsxis, O. R. \& Gordon, F. B. (1972). Pseudomonas aeruginosa exotoxin: effect on cell cultures. Journal of Infectious Diseases 125, 63I-636.

Pflüger, R., Scharmann, W. \& Blobel, H. (1975). Toxicity of culture supernatants from Pseudomonas aeruginosa. Zentralblatt für Bakteriologie, Parasitenkunde, Infektionskrankheiten und Hygiene (Abteilung I) (in the Press).

Pulverer, G. \& Korth, H. (I96I). Zur Biochemie und Fermentstruktur von Pseudomonas aeruginosa. Zentralblatt für Bakteriologie, Parasitenkunde, Infektionskrankheiten und Hygiene (Abteilung I) r86, 36-44.

Sbarra, A. J., Gilfillan, R. E. \& Bardawil, W. A. (i960). A plate assay for elastase. Nature, London I88, $322-323$.

Schaffer, A. J. \& Oppenheimer, E. H. (1948). Pseudomonas (Pyocyaneus) infection of the gastrointestinal tract in infants and children. Southern Medical Journal 4I, 460-466. 
ScharmanN, W. \& Balke, E. (1974). Untersuchungen über eine Protease (Elastase) von Pseudomonas aeruginosa. I. Bildung und Reinigung der Protease. Hoppe-Seyler's Zeitschrift für physiologische Chemie 355, 443-450.

SChARMAnN, W., JACOB, F. \& PorstendöRfer, J. (1976). The cytotoxic action of leucocidin from Pseudomonas aeruginosa on human polymorphonuclear leucocytes. Journal of General Microbiology 93, 303-308.

Seki, T., TAKaki, M., HiRabaYAshi, H. \& Yamaguchi, H. (I954). Toxin production by autolysis of Clostridium tetani. Medical Journal of Osaka University 5, 27I-289.

Sensakovic, J. W. \& BARTell, P. F. (1974). The slime of Pseudomonas aeruginosa: biological characterization and possible role in experimental infection. Journal of Infectious Diseases 129, IOI-109.

Teplitz, C. (1965). Pathogenesis of Pseudomonas vasculitis and septic lesions. Archives of Pathology 80, 297-307.

Turner, A. W. \& Rodwell, A. W. (1943). The epsilon toxin of Clostridium welchii type D. I. Proteolytic conversion of epsilon protoxin into episilon toxin by trypsin and other proteases. Australian Journal of Experimental Biology and Medical Sciences 21, 17-25. 